\title{
Towards a general theory of landscape systems: the integration of the geoecological and bioecological approaches
}

\begin{abstract}
Ever since its beginnings, landscape ecology has been developing in two different directions: the bioecological and the geoecological. While the bioecological approach is focused on the relationship between organisms and their abiotic environment, the geoecological approach is based on the relationship between human society and its, primarily abiotic, environment. Therefore, the geoecological approach can be applied in planning human use of the environment in a long term sustainable manner, while the bioecological approach could represent the basis for the planning of conservational and environmental usage. The merging of these two approaches will result in a comprehensive and more holistic landscape ecology, which will thus gain the potential for coordinating interdisciplinary landscape research and a more prominent role in contributing to spatial planning. The merge will also enhance attempts to create a general theory of landscape systems.
\end{abstract}

Keywords

Bioecology $\bullet$ geoecology $\bullet$ holism $\bullet$ landscape ecology $\bullet$ general theory of landscape systems

() University of Warsaw - Faculty of Geography and Regional Studies

\author{
Neven Tandarić \\ Croatian Geographical Society, Zagreb \\ e-mail: neven.tandaric@gmail.com \\ Received: 1 June 2014 \\ Accepted: 8 October 2014
}

\section{Introduction}

Since its beginnings, man has shown interest in the world in which he lives because that knowledge was necessary for his survival and coexistence with other organisms in a dynamic environment. As anthropogenic conditions and amenities in space evolved, so did the efforts to explain the causal links between various spatial components. One of the oldest disciplines seeking this accomplishment, even since the Classical period, was geography, although from a biotic point of view ecology has also been concerned with this task. Finally, the application of general geographical and geoscientific knowledge and methods in ecology in the 1930s inspired the German geographer Carl Troll to propose a new discipline - landscape ecology (Ger. Landschaftsökologie) - which aims to study ecological relationships and patterns in space at the landscape level. Given the interdisciplinary nature of its subject of study, the development of landscape ecology was dominated by geographers, ecologists and biologists directing it towards applicability in the field of spatial planning and environmental protection and conservation. Nowadays two dominant approaches in landscape ecological research can be observed: the geoecological and the bioecological approach (Naveh 1991; Brandt 1995; Cieszewska 2000; Moss 2000a,b; Bastian 2001; Farina \& Belgrano 2004; Wu 2006; McAlpine et al. 2010). The geoecological approach focuses on abiotic components in landscape and the applicability of research. The bioecological approach emphasizes the development of theoretical knowledge about primarily biotic components of landscape. Both approaches are mutually complementary and in line with the development of landscape ecology.
The aim of this paper is to compare the geoecological and bioecological approach in order to determine the similarities and differences between them as well as their importance for the development of integrative landscape ecology and the general theory of landscape systems. Based on this, an attempt will be made to define the internal hierarchical relations between ecology, geography, landscape ecology, and the geoecological and bioecological approaches in the system of science.

Previous contributions to the discussion about identity and approaches by landscape ecology

The dynamic development of landscape ecology and its approaches worldwide has resulted in a variety of perspectives on their position in the system of science. Geoecology is usually considered both a geographical and landscape ecological discipline, but there is still a vivacious debate questioning whether landscape ecology belongs to ecology or is an independent interdisciplinary field (Moss 2000b). Moss (2000a,b) and Opdam et al. (2002) discuss the issue of the identity of landscape ecology in the hierarchical system of science. This issue is a direct consequence of the fact that this is not a well-defined and recognizable subject of study, which is also indicated by the wide extent of various, mutually inconsistent definitions. While some authors give a clear definition of landscape ecology as an ecological discipline which studies the ecological interactions between organisms and their environment at the landscape level (Leser 1997; Fahrig 2005; Turner 2005; Molles 2008), other authors insist on functional definitions of landscape ecology as a study of the 
organization of landscape from the aspect of human use (Miklós 1994; Drdoš 1996). Some authors go even further, subsuming under the subject of landscape ecological study environment in its broadest sense (Miklós 1996), or the subjects of study of various other disciplines like geography, ecology, sociology, or biology as well as spatial planning, resource management, agricultural policies and environmental ethics (Wiens \& Moss 1999).

According to Moss (2000b), this is a consequence of the position of landscape ecology at the intersection of traditional disciplines such as geography and ecology, which are well distinguished and strong enough to expand their role to address the burning issues. Another important problem which arises from this position is the existence of two approaches - geoecological and bioecological which direct the research and the development of the discipline, and result in a lack of integration, required to define a unique and inherent subject of study (Moss 2000b; Opdam et al. 2002).

The geoecological approach, based on geocomplexes, enables a large contribution to be made by geographers (Bastian 2001). Back in 1982, Neef stressed that the first landscape ecologists were geographers, while Zonneveld (1972) in his earlier papers considered the structure of the abiotic environment to be the central subject of landscape ecological study, thus linking it more strongly to geography than ecology. Pavić (1987) points out that geoecology could be seen as a separate geographical discipline at the overlap of geography and ecology. In his more recent paper, Zonneveld (1990) describes landscape ecology as a "marriage" between geography (landscape) and biology (ecology), although he also names a number of other professions dealing with the field. Similarly, Fernandes et al. (2006) discuss the conditionality of landscape ecology by geography since it studies landscape, representing a spatial unit within which objects and processes constitute a geographical reality.

The papers on the potential of the application of landscape ecological knowledge, concepts and methods in spatial planning written by Opdam et al. (2002), Halás (2003), Bryl \& Łyczkowska (2010), Khoroshev (2010) and Mizgajski et al. (2010), show the possibility and the need for defining the contemporary landscape ecology as a multidisciplinary discipline. However, it is important to add that, through the development of its interdisciplinarity, landscape ecology could become one of the pillars of spatial planning (Tress, Tress \& Fry 2004), thus contributing to ecologically, socially and economically sustainable planning and management of the environment (Botequilha-Leitão \& Ahern 2002; Ahern 2005; Termoshuizen et al. 2007; McAlpine et al. 2010).

\section{A geoecological approach to landscape ecology}

The meaning of the term geoecology today, as well as in the past, is not unambiguous. In 1968 the founder of landscape ecology, Carl Troll, suggested the name geoecology (Ger. Geoökologie) as a synonym for landscape ecology which would be recognizable and usable in different languages. This term, however, has not taken root outside Central and Eastern Europe, and even there it does not have identical meanings (Bastian 2001). A literature review shows that the term geoecology is mostly in use in Eastern European countries where it was developed by geographers primarily for application in spatial planning, land use planning and natural resource management (Bastian 2001). However, geoecology there does not represent holistic landscape ecology, but rather an approach established in the geosciences. In Central Europe geoecology is a part of landscape ecology (Leser 1997; Melnyk 2008).

Various authors from different landscape ecology schools (Mezősi et al. 1993; Cieszewska 2000; Moss 2000b; Bastian 2001) agree upon geoecology being an approach based on geography which studies abiotic parameters and geocomplexes of the landscape in a comprehensive manner. As such, geoecology has strived to define the landscape through comprehensive and systematic interpretation of its formative components (landform, soil, vegetation, atmosphere, the impacts of land uses, energy, etc.), the combination of which creates specific spatial units landscapes (Moss 2000b). However, through the reductionist approach it focuses on the individual components of the landscape as if they exist together but are not interrelated, thus only acquiring knowledge about landscape composition, but not about the functional characteristics of the landscape (Naveh 2000). Consequently, Moss (2000b) and Naveh (2000) state that the basic weakness of the geoecological approach is the assumption that the functional characteristics of a landscape could be understood by combining the data from different disciplines dealing with the individual components of the landscape. In reality, knowledge about their interactions and their consequences is required because a landscape should be regarded according to the principle "the whole is greater than the sum of its parts". This way geoecological research would be less focused on the impacts of various factors of the landscape and more focused on the functional characteristics of the landscape (Moss 2000b). The real holistic perspective would ensure that a landscape is considered as an interactive system in which components are interrelated by functional links. This perspective would also ensure the awareness of the fact that every impact on any component of the landscape would, directly or indirectly, and to a greater or lesser extent, reflect on all the other components whose mutual causal interrelationships constitute the landscape system (Naveh 2000).

The important positive characteristic of the Central European geoecological approach is the role of humans as an integral part of the landscape instead of being considered an external factor. Most landscapes on Earth represent a habitat, a working space, a source of raw materials and energy or a recreation area and are thus in constant interaction with man. Another positive characteristic is the focus on landscape in a scale relevant to human perception and action (Wiens 2002; Farina \& Belgrano 2004). According to Mezősi et al. (1993) this is the reason why geoecology can answer the issues related to land use or the assessment of environmental impacts, and can therefore be the basis for political decisions and regional planning.

In Eastern European countries geoecology is mainly considered to be the part of geography concerned with any issues regarding the interactions between nature and society (Melnyk 2008). When identifying geoecology with "landscape ecology" as a comprehensive physical geography, Ostaszewska (2004) gives an unconventional view on geoecology and denies its identification with landscape ecology. According to this author, landscape geography studies the relationships between the components of landscape, and this is what earned it a synonym implying ecology.

The third dominant view is the one identifying geoecology with landscape ecology, following the proposal Troll gave upon creating the term Geoökologie. Naveh (2000) and Richling \& Solon (1996) oppose such a view, arguing that current geoecology focuses on the abiotic components of the landscape while landscape ecology presupposes a much broader subject of study than the abiotic components of the landscape, i.e. the landscape as a whole consisting of abiotic, biotic and social components.

\section{The bioecological approach to landscape ecology}

Bioecology represents a branch of ecology which studies the interactions between organisms and their biotic and abiotic environment, not embracing human ecology (Clements \& Shelford 1939). A concern with organisms excluding humans is inherited from classical ecology, which has shied away from studying the complex relationships between organisms, society and their shared environment (Naveh 2005). This branch of ecology laid the 
foundations for the bioecological approach to landscape ecology which began its development in North America and was primarily directed toward the development of theory (Forman \& Godron 1986; Farina 1993; Moss 2000b; Bastian 2001).

The bioecological approach presupposes the bioecological research of landscape aimed at the understanding of the spatial dimensions of populations of organisms and ecological problems arising from them (Moss 2000b). Therefore, bioecological research in landscape ecology is focused primarily on the structural characteristics of landscape important to ecological processes (Turner 1989; Bastian 2001; Opdam et al. 2002), which in turn influence the abundance and distribution of organisms (Fahrig 2005). According to Moss (2000b), the key reason for the existence of the bioecological approach is the development of knowledge about plant and animal communities where landscape is only the broader context in which they are studied.

Such a limited aspect precisely represents the main weakness of the bioecological approach. Another important weakness is neglecting the role of human society as the key component in affecting the structure and processes of a landscape. Considering the human use of landscape, bioecological processes become intertwined with social and economic processes; the bioecological approach should broaden its focus to integrate these processes (McAlpine et al. 2010). This factor has induced bioecological research of urban landscapes in recent years, but they are still concerned with the distribution and dynamics of plants and animals affected by humans as external agents (Wu 2008), instead of observing human society and other organisms as equivalent components of the landscape in continuous interaction.

On the other hand, the advantage of the bioecological approach is its consideration of landscape as a dynamic environment. Bioecological application in the field of bioconservation and spatial planning is focused on the preservation of processes rather than the present ecological conditions (Bonnin et al. 2007). This is the reason why the bioecological approach is the source of many important landscape ecological concepts, based mainly on the dynamics of populations of organisms, such as the following: patch-corridor-matrix model, greenways, connectivity, habitat networks, biocorridors, ecological barriers, etc. (Bastian 2001; Barsch et al. 2002).

Comparison of the geoecological and the bioecological approach

The focus on abiotic components of a landscape in geoecological research is as undeniable as the focus on biotic components in bioecological research. In geocology, geocomplexes are recognized as the spatial elements of a landscape. Every geocomplex represents a relatively enclosed spatial element completed by the relationships and processes of its components (Cieszewska 2000). On the other hand, bioecological approach applies the patch-corridor-matrix concept (Forman \& Godron 1986) in which biotic components of land are the main criterion to determine the spatial elements of a landscape. This concept distinguishes spatial elements as patches connected by corridors, while both of them are embedded in a uniform matrix which consists of a predominant type of land cover in the landscape (Cushman et al. 2010). The main advantage of this concept is its functional aspect. The landscape is observed through the relationships between elements while the abiotic components are of lesser importance (Cieszewska 2000). In combination with the knowledge acquired in ecological research, this approach enables projections of the ecological activities of organisms in a landscape. On the other hand, the concept of the geocomplex is based on the spatial arrangement of landscape components which, through their interrelationships, form spatially delimited geocomplexes. Various forms of individual components lead to different interaction results, which is why geocomplexes mutually differ (Cieszewska 2000).

Both approaches have the potential for application in planning from the local to the regional and national levels, and the selection of the approach should correspond with the purpose of the research (Cieszewska 2000). Applied geoecological research has been characterised from the beginning by an anthropocentric focus and therefore has a significant effect on land use planning. In contrast, the bioecological approach is characterized by a biocentric focus and is therefore more applicable to the conservation of organisms in the landscape (Turner 2005), although its potential for planning human use of the environment is increasingly exploited. In a comprehensive landscape study these approaches are complementary.

The need for integration of the geoecological and bioecological approaches

Clearly neither the geoecological nor the bioecological approach in landscape ecology have a fully holistic perspective on landscape since they do not focus on the characteristics of the landscape as a whole, composed of abiotic, biotic and anthropic elements interrelated with various functional processes. According to Naveh (2002) it is precisely this perspective that represents the subject of study of landscape ecology. Moss (2000b) postulates that landscape ecology will only mature if these two approaches merge. The lack of integration of these approaches can be considered the main answer to the question of why landscape ecological knowledge is not yet sufficiently applied in spatial planning (Opdam et al. 2002).

Many landscape ecologists (Neef 1967; Zonneveld 1990, 1995; Naveh 1991; Richling \& Solon 1996) directly or indirectly suggest that landscape as a spatial system consists of the geosphere, the biosphere and the noosphere. The geosphere includes all the abiotic components of the environment (atmosphere, hydrosphere, pedosphere, lithosphere). The biosphere can be understood as the total of all the biotic components (organisms) while the noosphere represents the sphere of human thoughts and consciousness which are reflected in the landscape through anthropogenic transformations of the natural environment and the input of human artefacts (Naveh 1991, 2000). The study of landscape as a system made up of these three spheres requires the use of knowledge of various natural and social sciences in order to transcend the bioecosystem level of landscape and move on to the so called geo-bio-anthropo-level that Naveh (1991) calls the Total Human Ecosystem. This system integrates man and his whole environment in a series of scales from the landscape to the entire ecosphere (global level). In this way landscape ecology becomes an integrative science of the total human ecosystem, linking bioecology with human ecology.

Bearing in mind that human actions, as well as their material and immaterial reflections, have become an indispensable part of the landscape, it is clear that the study of the relations between biotic and abiotic components of landscape is incomplete without functional connections to anthropic components. The goal is to achieve a comprehensive understanding of the current environmental conditions of landscapes and the possibilities for making ecologically and socially acceptable changes to these conditions (Wu \& Hobbs 2002). The relationship between man and his biotic and abiotic environment represents the subject of human ecology (Rambo 1983; Richerson et al. 1996). This could be linked to the fact that geoecology in Europe has a tradition of considering society and its activities to be an integral part of the landscape (Wu \& Hobbs 2002), in order to build an integrative socio-economic model of the landscape which could contribute to environmental problem solving (Farina 1993). In this way, geoecology could be recognized as a human ecological approach which studies the 
relationships between man and his environment (BotequilhaLeitão \& Ahern 2002). This could be considered an argument for Moss' (2000b) claim that a comprehensive ecological perspective of a landscape, which includes abiotic, biotic and human components, should be reached by the integration of bioecology and geoecology.

\section{Disciplinary identity of landscape ecology}

There is a clear consistency between Häckel's original (Odum \& Barrett 2005) and Molles' (2008) recent definitions of ecology as the study of relationships between organisms and the environment, and Troll's (1971) definition of landscape ecology as the study of the main complex causal relationships between communities of organisms and their environment. Landscape ecology uses the subject of ecology, limiting it spatially to the scale of the landscape. In his comprehensive review of ecological disciplines, approaches and research, Molles' (2008) classifies the disciplines according to a synthetic ecological-spatial criterion - as the ecology of the individual, the ecology of the community, the ecology of the ecosystem, landscape ecology, geographical ecology and global ecology - thus indicating the functional role played by landscape ecology in the system of ecological science.

In the previous section, the arguments regarding the need for the integration of the geoecological and bioecological approaches for the purpose of the holistic explanation of features and processes in landscape were presented. Considering the stated subject of bioecology and human ecology, the division of ecological science into these two branches is quite legitimate. Thereby Molles' (2008) hierarchy of disciplines from the ecology of the individual to the ecology of the ecosystem can be applied to both branches with the difference lying only in the focal object humans or other organisms. The necessary integration of these two branches is expected at the landscape scale because this is the spatial level at which man interacts with his biotic and abiotic environment; it is the level at which the intertwining of the human and natural systems, which represents the subject of landscape ecology, can be explored (Wu \& Hobbs 2002; Wu 2006).

Taking all this into consideration, landscape ecology can develop the identity of a unique integrative field within ecology which will study the material and functional characteristics of landscapes as specific spatial systems shaped by functional relationships and the interactions of abiotic, biotic and anthropic components. This spatial and functional heterogeneity, according to $\mathrm{Wu}(2006)$, is what makes the landscape perspective relevant to ecology at different organizational levels.

\section{An interdisciplinary concept of landscape ecology}

Although landscape ecology, regarding the arguments previously presented, can be considered a part of ecology, it can and should approach the investigation of landscape interdisciplinarily, providing the ecological base for a wide range of landscape research from various aspects. According to Wu \& Hobbs (2002), this standpoint was suggested by all American landscape ecologists participating in the $16^{\text {th }}$ Annual Symposium of the US Regional Association of the International Association of Landscape Ecology in 2001. They also expressed an awareness that the current landscape ecology is more multidisciplinary than interdisciplinary, which makes it difficult to develop an integrative knowledge of landscape which cannot be reached through the individual investigations of separate disciplines (Tress et al. 2004). Moreover, Moss (2000a) points out that experience has taught us that virtually all environmental issues transcend single discipline bounds. The impossibility of reducing environmental and landscape issues to one discipline is the main reason behind the lack of potential of the contemporary academic community to solve various ecological and social problems (Moss 2000b). Therefore, it is crucial for landscape ecologists not to prevent scientists from different disciplines contributing to the formation of the subject of landscape ecology. Responding to the resistance of some landscape ecologists, Wu (2006) stressed that the integration of different disciplines and the prominence of the holistic perspective do not mean distancing the discipline from the ecological subject of study, but rather its increased integration with the social and economic components of landscape, in order to solve problems and meet the needs which arise from the planning and management of landscape.

Due to its multidisciplinarity, landscape ecology nowadays presupposes a wide range of approaches, theories and methodologies, with this heterogeneity being the result of different landscape conceptions, scientific backgrounds and specializations (Bastian 2001). Although landscape is not the exclusive subject of any discipline (Moss 2000b; Tress et al. 2004), in order to be called a scientific discipline, landscape ecology must define a unique approach to landscape research which is able to generate methods for its investigation (Moss 2000b). The great opus of perspectives, theories and concepts gathered around the ecological theoretical and methodological basis of landscape ecology could be put into service in developing a general (interdisciplinary) theory of landscape systems (Chmielewski 2008, 2011, 2012). This theory should explain the structure and functioning of landscapes as systems shaped by interactions between all components of the geosphere, biosphere and noosphere. Because of its appropriate foundation for the development of a holistic research concept to study landscapes, landscape ecology has the potential to take the leading role in the coordination of interdisciplinary research on landscapes, in order to develop a general theory of landscape systems. Once this theory begins to be formed, its knowledge could be used in practice i.e. spatial planning, land use management, and conservation management.

\section{Conclusion}

It is significant that after more than 70 years in existence there are still certain open questions regarding the subject of landscape ecology, its research approaches and its position in the system of science. One of the reasons is its two-sided development in Europe and North America, based on knowledge and principles from different sciences and an orientation in different directions. The European geoecological approach lacks biotic knowledge while the North American bioecological approach neglects the societal components of landscape. By merging these two separated approaches, their knowledge and methods, and by developing a comprehensive synergetic research concept, the developmental goal of landscape ecology would be achieved. It will become an interdisciplinary field which, through the integration of an ecological base and knowledge from different disciplines dealing with the environment and its components, explains the functional processes and spatial reality of a landscape as a mutual living place of humans and other organisms. This comprehensiveness will allow it to become the main actor in developing a general theory of landscape systems.

\section{Acknowledgment}

The author would like to thank Maja Čatlak for her help with the traslation to English and proofreading of this paper. 
Ahern, J 2005, 'Theories, methods and strategies for sustainable landscape planning' in From Landscape Research to Landscape Planning: Aspects of Integration, Education and Application eds B Tress, G Tress, G Fry \& P Opdam, Springer, Frankfurt, pp. 119-131.

Barsch, H, Bastian, O, Beierkuhnlein, C, Bosshard, A, Breuste, J, Klötzli, F, Otl, K, Tress, B, Tress, G \& Weiland, U 2002, 'Application of landscape ecology' in Development and Perspectives of Landscape Ecology eds O Bastian \& U Steinhardt, Springer, Dordrecht, pp. 307-432.

Bastian, O 2001, 'Landscape Ecology - towards a unified discipline?', Landscape Ecology, vol. 16, pp. 757-766.

Bonnin, M, Bruszik, A, Rientjes, S, Delbaere, B, van Uden, G, Léthier, H, Richard, D \& Terry, A 2007, The Pan-European Ecological Network: Taking Stock, United Nations, New York.

Botequilha-Leitão, A \& Ahern, J 2002, 'Applying landscape ecological concepts and metrics in sustainable landscape planning', Landscape and Urban Planning, vol. 59, pp. 6593.

Brandt, J 1995, 'Landscape ecology and the destiny of geography', Landscape Ecological Papers, vol. 9, pp. 55-61.

Bryl, M \& Łyczkowska, G 2010, 'Spatial planning as an instrument for shaping an ecological network', The Problems of Landscape Ecology, vol. 28, pp. 77-83.

Chmielewski, TJ 2008, 'Zmierzając ku ogólnej teorii systemów krajobrazowych', The Problems of Landscape Ecology, vol. 21, pp. 93-108.

Chmielewski, TJ 2011, 'Landscape systems: spatial structure and speed of changes', The Problems of Landscape Ecology, vol. 30, pp. 23-30.

Chmielewski, TJ 2012, 'Systemy krajobrazowe: Struktura funkcjonowanie - planowanie', Wydawnictwo Naukowe PWN, Warszawa.

Cieszewska, A 2000, 'Comparative landscape structure studies for land use planning - Przedborski landscape park case study', The Problems of Landscape Ecology, vol. 6, pp. 54-62.

Clements, F \& Shelford, V 1939, Bio-ecology, Jonh Wiley \& Sons, New York.

Cushman, S, Evans, J \& McGarigal, K 2010, 'Landscape Ecology: Past, Present and Future' in Spatial Complexity, Informatics, and Wildlife Conservation, eds E Landguth \& F Huettmann, Springer, New York, pp. 65-82.

Drdoš, J 1996, 'A reflection on landscape ecology', Ekológia (Bratislava), vol. 15, pp. 369-375.

Fahrig, L 2005, 'When is a Landscape Perspective Important?' in Issues and Perspectives in Landscape Ecology, eds JA Wiens \& MR Moss, Cambridge University Press, Cambridge, pp. $3-10$.

Farina, A 1993, 'From global to regional landscape ecology', Landscape Ecology, vol. 8, pp.153-154.

Farina, A \& Belgrano, A 2004, 'The eco-field: a new paradigm for landscape ecology', Ecological Research, vol. 19, pp. 107-110.

Fernandes, J, Guiomar, N \& Soares, A 2006, 'Geometries in Landscape Ecology', Journal of Mediterranean Ecology, vol. 7, no. 1-4, pp. 3-13.

Forman, RTT \& Godron M 1986, Landscape ecology, John Wiley \& Sons, New York.

Halás, M 2003, 'Possibilities for the application of geography to land use planning', Acta Universitatis Carolinae Geographica, vol. 1, pp. 67-77.

Khoroshev, A 2010, 'Multilevel analysis of landscape structure for land use decisions' in Landscape ecology - methods, applications and interdisciplinary approach, eds $\mathrm{M}$ Barančoková, J Krajči, J Kollár \& I Belčáková, Institute of Landscape Ecology, Slovak Academy of Sciences and Institute of Garden and Landscape Architecture, Faculty of Architecture, Slovak University of Technology, Bratislava, pp. 99-112.

Leser, H 1997, Landschaftsökologie, Ulmer, Stuttgart.

McAlpine, C, Seabrook, L, Rhodes, J, Maron, M, Smith, C, Bowen, M, Butler, S, Powell, O, Ryan, J, Fyfe, C, Adams-Hosking, C, Smith, A, Robertson, O, Howes, A \& Cattarino, L 2010, 'Can a problem-solving approach strengthen landscape ecology's contribution to sustainable landscape planning', Landscape Ecology, vol. 25, pp. 1155-1168.

Melnyk, A 2008, 'Ecological analysis of landscapes' in Methodology of landscape research, ed V Andreychouk, Sosnowiec, pp. 151-169.

Mezősi, G, Bárány-Kevei, I, Mucsi, L \& Balogh, I 1993, 'First results of GIS based geoecological mapping', Acta Geographica Szegediensis, vol. 31, pp. 71-82.

Miklós, L 1994, Landscape ecological principles of the sustainable development, Roskilde University, Department of Geography and International Development Studies, Roskilde.

Miklós, L 1996, 'Landscape-ecological theory and methodology: a goal oriented application of the traditional scientific theory and methodology to a branch of a new quality', Ekológia (Bratislava), vol. 15, pp. 377-385.

Mizgajski, A, Breuste, J, Albert, C, Gruehn, D, Kozová, M, Miklós, L \& Mörtberg, U 2010, 'Implementation of landscape ecological knowledge - achievements and challenges', The Problems of Landscape Ecology, vol. 28, pp. 9-13.

Molles, M 2008, Ecology: Concepts and Applications, McGrawHill, New York.

Moss, MR, 2000a, 'Interdisciplinarity, landscape ecology, and 'The transformation of agricultural landscapes", Landscape Ecology, vol. 15, pp. 303-311.

Moss, MR 2000b, 'Landscape ecology: the need for a discipline?', The Problems of Landscape Ecology, vol. 6, pp. 174-187.

Naveh, Z 1991, 'Some remarks on recent developments in landscape ecology as a transdisciplinary ecological and geographical science', Landscape Ecology, vol. 5, pp. 6573.

Naveh, Z 2000, 'What is holistic landscape ecology? A conceptual introduction', Landscape and Urban Planning, vol. 50, pp. $7-26$.

Naveh, Z 2002, 'Foreword' in: Development and Perspectives of Landscape Ecology, eds O Bastian \& U Steinhardt, Springer, Dordrecht, pp. xxi-xxvii.

Naveh, Z 2005, 'The transformation of landscape ecology and restoration ecology into transdisciplinary sciences of holistic landscape study, management and planning, conservation and restoration' in: Transdisciplinary Challenges in Landscape Ecology and Restoration Ecology, Springer, Dordrecht, pp. 353-401

Neef, E 1967, Die theoretischen Grundlagen derLandschaftslehre, Hermann Haack: Geographisch-Kartographische Anstalt Gotha, Leipzig.

Neef, E 1982, 'Stages in the development of landscape ecology' in Perspectives in Landscape Ecology: Proceedings of the 1st International Congress in Landscape Ecology, eds S Tjallingii \& A de Veer, Center for Agricultural Publishing and Documentation, Wageningen, pp. 19-28.

Odum, E \& Barrett, G 2005, Fundamentals of Ecology. Thomson Brooks/Cole, Belmont. 
Opdam, P, Foppen, R \& Vos, C 2002, 'Bridging the gap between ecology and spatial planning in landscape ecology', Landscape Ecology, vol. 16, pp. 767-779.

Ostaszewska, K 2004, 'Four fundamental methodological problems of landscape geography', Miscellanea Geographica, vol. 11, pp. 13-17.

Pavić, R 1987, 'Osnove kompleksne ekologije i geoekologije za geografe - temeljne definicije i prijedlog nastavnog plana', Geografski glasnik, vol. 49, pp. 90-96.

Rambo, T 1983, Conceptual Approaches to Human Ecology, East-West Environment and Policy Institute, Honolulu.

Richerson, P, Mulder, M \& Vila, B 1996, Principles of Human Ecology, Simon \& Schuster, Needham Heights.

Richling, A \& Solon, J 1996, Ekologia krajobrazu. PAN, Warszawa.

Termorshuizen, J, Opdam, P \& van den Brink, A 2007, 'Incorporating ecological sustainability into landscape planning', Landscape and Urban Planning, vol. 79, pp. 374-384.

Tress, G, Tress, B \& Fry, G 2004, 'Clarifying integrative research concepts in landscape ecology', Landscape Ecology, vol. 20, pp. 479-493.

Troll, C 1971, 'Landscape ecology (geoecology) and biogeocenology: a terminological study', GeoForum, vol. 8, pp. 43-46.

Turner, M 1989, 'Landscape ecology: The effect of pattern on process', Annual Review of Ecology and Systematics, vol. 20, pp. 171-197.
Turner, M 2005, 'Landscape ecology: What is the state of the science?', Annual Review of Ecology, Evolution, and Systematics, vol. 36, pp. 319-344.

Wiens, JA 2002, 'Riverine landscapes: taking landscape ecology into the water', Freshwater Biology, vol. 47, pp. 501-515.

Wiens, JA \& Moss, MR 1999, 'Preface' in Issues in Landscape Ecology, eds JA Wiens \& MR Moss, IALE, Snowmass.

Wu, J 2006, 'Landscape ecology, cross-disciplinarity, and sustainability science', Landscape Ecology, vol. 21, pp. 1-4.

$\mathrm{Wu}, \mathrm{J}$ 2008, 'Making the Case for Landscape Ecology: An Effective Approach to Urban Sustainability', Landscape Journal, vol. 27, pp.1-8

Wu, J \& Hobbs, RJ 2002, 'Key issues and research priorities in landscape ecology: An idiosyncratic synthesis', Landscape Ecology, vol. 17, pp. 355-365.

Zonneveld, I 1972, Textbook of photo-interpretation, ITC, Enschede.

Zonneveld, I 1990, 'Scope and Concepts of Landscape Ecology as an Emerging Science' in Changing Landscapes: An Ecological Perspective, eds I Zonneveld \& RTT Forman, Springer, New York, pp. 3-20. 